Open Access | Research Article

\title{
Management of acute upper gastrointestinal bleeding
}

Eduardo Esteban-Zubero ${ }^{1 *}$; Elisabet Sarmiento-Acosta²; Sara Sáez-Jiménez ${ }^{3}$; Moisés Alejandro Alatorre-Jiménez ${ }^{4}$; Alejandro Marín-Medina ; Marta Olga Asín-Corrochano ${ }^{6}$; Rocío Villeda-González; ; Carlos Arturo López-García ${ }^{8}$; José Juan Gómez-Ramos ${ }^{9}$

${ }^{1}$ Medical Doctor in Emergency Department of Hospital San Pedro (Logroño, Spain).

${ }^{2}$ Primary Care Resident in Cascajos Health Center (Logroño, Spain).

${ }^{3}$ Primary Care Resident in Joaquín Elizalde Health Center (Logroño, Spain).

${ }^{4}$ Department of Neurosciences, Western biomedical research center, Mexican Institute of Social Security (Guadalajara, Mexico).

${ }^{5}$ Department of Genetics, Western biomedical research center, Mexican Institute of Social Security (Guadalajara, Mexico).

${ }^{6}$ Resident in Intensive Care Unit of Hospital Clínico Universitario Lozano Blesa (Zaragoza, Spain)

${ }^{7}$ Research Department, Asociación Mexicana de Atrofia Muscular Espinal (AMAME). Chápala 26, 44101 (Guadalajara, Mexico).

${ }^{8}$ Mission Regional Medical Center. 900 S Bryan Rd, Mission Tx 78572, USA.

${ }^{9}$ Medical Doctor in Emergency Department of Instituto Mexicano de la Seguridad Social (Hospital 89, Mexico).

\author{
*Corresponding Author(s): Eduardo Esteban-Zubero, \\ Medical Doctor in Emergency Department of Hospital \\ San Pedro, Logroño, Spain \\ Tel: +34-65-412-3994; Email:eezubero@gmail.com
}

Received: Feb 27, 2018

Accepted: Mar 12, 2018

Published Online: Mar 20, 2018

Journal: Annals of Gastroenterology and the Digestive System Publisher: MedDocs Publishers LLC

Online edition: http://meddocsonline.org/

Copyright: (C) Zubero EE (2018). This Article is distributed under the terms of Creative Commons Attribution 4.0 International License

Keywords: Upper gastrointestinal bleeding; Nonsteroidal antiinflammatory drugs; Endoscopy

\section{Abstract}

The purpose of this review is to summarize the management of upper gastrointestinal bleeding (UGIB). This entity has an annual incidence of 48 to 160 cases per 100,000 adults, with a mortality rate of $10 \%$ to $14 \%$. Classically, UGIB is divided in non-variceal hemorrhage and variceal hemorrhage, being more frequently observed the first one (80\%$90 \%)$. The initial management includes investigate about the form of presentation, color and characteristics of the hemorrhage, the age of the patient, presence of coagulopathy, disease or cardiovascular risk factors, use of nonsteroidal anti-inflammatory drugs (NSAIDs), antiaggregants or anticoagulants, previous episodes of hemorrhage, endoscopy, alcohol intake, etc. However, this process must not delay the initiation of hemodynamic resuscitation in patients with patients with ongoing bleeding. To stratify these patients, risk scores including Blatchford score and Rockall score are developed.

Diagnosis is realized through endscopy, which allows definitive treatment. This treatment is improved providing pre-endoscopy as well as post-endoscopy therapy, including proton pump inhibitor (PPI) therapy. In variceal hemorrhage, if endoscopy therapy fails, balloon tamponade or transjugular intrahepatic portosystemic shunt (TIPSS) are indicated.

The purpose of this review is to summarize the initial management of acute UGIB, especially in the Emergency Department.

Cite this article: Esteban-Zubero E, Sarmiento-Acosta E, Sáez-Jiménez S, Alatorre-Jiménez MA, Marín-Medina A, et al. Management of acute upper gastrointestinal bleeding. Ann Gastroenterol Dig Syst. 2018; 1: 1002. 


\section{Introduction}

Upper gastrointestinal bleeding (UGIB) is the loss of blood through the gastrointestinal tract whose origin proximal to the Treitz angle [1]. This entity has an annual incidence of 48 to 160 cases per 100,000 adults [2-4], with a mortality rate of $10 \%$ to $14 \%$ [5]. The rates of UGIB are higher in men and the elderly, and poorly tolerated shock, with destabilisation of underlying organ disease and severe coexistent comorbidities increase the risk of mortality [6].

Classically, UGIB is divided in non-variceal hemorrhage and variceal hemorrhage. Table 1 summarizes the main etiologies of acute UGIB [7].

Acute UGIB manifests as vomiting of blood (haematemesis) and/or passage of black, tarry stools (melena). The last one may be caused by bleeding from the small intestine downwards the duodenum. Tarry stools are usually seen if more than $50 \mathrm{~mL}$ to $100 \mathrm{~mL}$ of blood is lost per day. The passage of bright red blood per rectum (haematochezia) could be caused by severe brisk bleeding. If more than $10 \%$ to $20 \%$ of the total intravascular blood volume is lost, haemodynamically instability (hypotension, tachycardia) is observed [8].

The purpose of this review is to summarize the initial management of acute UGIB, especially in the Emergency Department.

\section{Initial management}

As we described previously, UGIB could be manifested as haemodynamically instability. Due to that, anamnesis should not delay resuscitation if it is necessary.

During the interview, it is important to ask about the quality and quantity of vomited blood (fresh red or coffee grounds), presence of melaena, syncope and alcohol consumption. Significant comorbidities, any past history of UGIB should be also known. In addition, use of non-steroidal anti-inflammatory drugs (NSAIDs), antiplatelet agents, anticoagulants, corticosteroids, and selective serotonin reuptake inhibitors (SSRIs) should be also noted due the increased risk of gastrointestinal (GI) bleeding observed with its intake [9].

Physical exploration includes documentation of cardiac frequency, blood pressure, and capillary refill time. These parameters should be monitored, including urine output and blood glucose. In addition, stigmata of chronic liver disease suggest variceal hemorrhage [7].

Attending to resuscitation, in the presence of hypovolaemic shock, should be administered 1-2 liters of crystalloids solutions [10]. Blood transfusion is also recommended if it is necessary. International consensus guidelines recommend it if the haemoglobin $(\mathrm{Hb}$ ) level is $\leq 70 \mathrm{~g} / \mathrm{L}$ [11]. On the other hand, some authors suggested transfusion in patients with clinical significant coexisting illness and red blood cell count of $90 \mathrm{~g} / \mathrm{L}$ or delayed therapeutic intervention $[12,13]$. However, recent evidence has shown that adopting a restrictive transfusion strategy, and not transfusing until the $\mathrm{Hb}$ falls below $<70 \mathrm{~g} / \mathrm{L}$, is associated with improved survival, a reduced risk of rebleeding and complications [14]. Coagulopathy should be also corrected. The National Institute for Health and Care Excellence (NICE) in a recent guideline specified the following criteria to correct it [15]:

Platelets should only be given if the patient is actively bleeding or haemodynamically unstable and has a platelet count of $<50 \times 10^{9} / \mathrm{L}$.

Fresh frozen plasma should be given if the fibrinogen level is $<1 \mathrm{~g} / \mathrm{L}$ or the prothrombin time (PT) or activated partial thromboplastin time is $>1.5$ times normal.

Prothrombin complex should be provided to those on warfarin and actively bleeding.

Recombinant factor VIla should only be used when all of the above measures have failed.

Finally, all patients admitted in the Emergency Department due to UGIB should be stratified into low and high risk according to validated prognostic scales. The Blatchford score (Table 2) should be used in every patient on initial presentation [16]. The Rockall score (Table 3) may also be used, but requires the realization of an endoscopy to be fully completed [17].

\section{Diagnosis}

Diagnosis process is based in laboratory test as well as endoscopy. The first one is required to elaborate risk scores previously described and provide blood transfusion if it is necessary. In addition, lactate levels are related with outcomes [18-20]. In addition, a systematic review found that a blood urea nitrogen $(B U N): C r$ ratio of greater than 30 is $93 \%$ specific for a UGIB, with a positive likelihood ratio of 7.5 [21].

\section{Endoscopy}

Endoscopy is the initial procedure in patients with LGIB due to its diagnosis as well as potentially therapeutic benefits. Adequate preparation is necessary to improve the outcomes of this technique. Proton pump inhibitor (PPI) therapy is commonly given to patients prior to endoscopy; however, this treatment has been not shown to alter clinically important outcomes such as mortality, rebleeding rate and need for surgery [22]. Due to that, this treatment should not delay an early endoscopy [7]. Similar results are observed with tranexamic acid (TXA). This drug have been shown to be beneficial in critically ill trauma patients due to the significant reduce of the risk of death [23]. However, ilts role in acute UGIB remains unclear. A large study examining the potential benefit of TXA with plans to enroll 8000 patients is currently under way [24].

Early endoscopy (within 24h) provides the opportunity to realize a prompt treatment, which reduces transfusion requirements, rebleeding and need for surgery [25].

\section{Treatment}

UGIB treatment depends of the etiology. Due to that, we are going to summarize it attending to the presence or absence of variceal.

\section{Non-variceal hemorrhage}

Endoscopy provides a range of techniques to stop as well as prevent further bleeding. It includes injection (adrenaline), thermo-ablative (coagulation probes) and mechanical (clipping) therapies. Nowadays is suggested to combine these techniques to improve the outcomes $[7,26]$. Adrenaline injection promotes a local vasoconstriction and tamponade effect, which allows stopping the bleeding applying a thermo-ablative or mechanical therapies on the vessel.

If the initial endoscopic treatment was unsatisfactory, repeat endoscopy should be considered when initial endoscopic treatment was considered to be suboptimal or a high risk of rebleed- 
ing is observed, it is suggested to repeat the endoscopy [27].

New treatments as topical haemostatic powders have been added to the therapeutic options of UGIB in selected cases. These therapies include Hemospray, Endoclot, and Blood Stopper. Hemospray effect is based in its capacity to absorb water and forms a cohesive and adhesive gel in contact with, which stops bleeding through a combination of mechanical effects (tamponade) and possible pro-coagulatory effects on platelets and clotting factors [28-30]

If endoscopic treatment fails, interventional radiology for angiographic embolisation or surgery should be realized [7].

After the endoscopy PPI therapy is suggested to be provided in patients with high-risk endoscopic lesions treated endoscopically. A meta-analysis observed that omeprazole $80 \mathrm{mg}$ bolus followed by $8 \mathrm{mg} / \mathrm{h}$ infusion for $72 \mathrm{~h}$ decreased mortality ratio in high risk patients [31]. These results were not observed in patients with low as well as intermediate risk. .PPI treatment should be provided during $72 \mathrm{~h}$ due to $60 \%$ to $76 \%$ of re-bleeding occurred in the first three days [32-34].

In addition, a urease test should be routinely performed at the time of endoscopy in patients with peptic ulceration to despite Helicobacter pylori infection. $\mathrm{H}$. pylori eradication is effective in reducing recurrent peptic ulcer bleeding and is more effective than PPI therapy alone [35]. If urease test is positive, it is recommended togive PPI therapy for at least 3 weeks after eradication [36]. Finally, if antiplatelet and anticoagulant agents need to be given after resolution of UGIB, concomitant treatment with omeprazole significantly reduced the rate of ulcer bleeding with no significant increase in cardiovascular events [37].

\section{Variceal hemorrhage}

\section{Endoscopic therapy}

In oesophageal varices, variceal band and sclerotherapy provide similar results iin terms of rebleeding rate, mortality rate and rate of death due to rebleeding [38]. Due to that, hospital conditions, operator experience, and the characteristics of esophageal varices should be considered to choice the treatment.

Gastric varices may be classified according to their location and relationship to oesophageal varices. Gastroesophageal varices (GOV) type 1 are defindes as those that continue from oesophageal varices and extend for $<5 \mathrm{~cm}$ along the lesser curvature of the stomach. If gastroesophageal varices extend towards the fundus along the greater curvature are defined as GOV type 2. On the other hand, isolated gastric varices (IGV) are not in continuation with oesophageal varices and may be in the fundus (IGV type 1) or anywhere distally (IGV type 2) [7]. A Cochrane review observed cyanoacrylate superglue injection is more effective than band ligation in terms of initial haemostatic control, rebleeding rate, need for blood transfusion and treatment-induced ulcer bleeding. However, due to the very low quality of the evidence, authors did not provide a preference of treatment [39].

\section{Pharmacotherapy for variceal bleeding}

Vasoactive drugs reduce portal hypertension by decreasing portal blood flow. These treatments include terlipressin and somatostatin or its analogues (such as octreotide). Terlipressin treatment is preferred due to it is the only one to have shown a reduction in mortality [40]. However, recent studies observed similar results in both treatments in oesophageal varices as well as gastric varices $[41,42]$. Both treatments should be started promptly if variceal bleeding is suspected and continued after endoscopy for at In addition, cirrhotic patients with variceal bleeding which have sepsis on admission, should be also treated with antibiotic. This effect is produced due to its capacity to mitigate the sepsis-induced systemic endotoxin release, which promotes an increase in portal pressure due to local vasoconstriction and a rise in intrahepatic vascular resistance [43]. Antibiotics which could be given include ceftriaxone, norfloxacin, ciprofloxacin or other broad spectrum antibiotics such as tazocin.

Like non-variceal hemorrhage, PPI therapy is commonly employed after variceal band ligation due to the decrease of the risk of bleeding [44] as well as the decreased number of ulcers after variceal banding [45].

\section{Rescue therapy for variceal bleeding}

$10 \%-20 \%$ of variceal bleeding continues despite combined pharmacological and initial endoscopic therapy. If there is cardiovascular compromise, balloon tamponade with a Sengstaken-Blakemore tube can be life-saving. This technique is also effective in massive variceal bleeding where endoscopy fails to identify or adequately treat bleeding varices. Successful outcomes are observed in around $80 \%$ of patients. However, complications including aspiration, tube migration and oesophageal necrosis or perforation occur in as many as $20 \%$ [46].

In patients with variceal bleeding, an hepatic venous pressure gradient (HVPG) of $>20 \mathrm{mmHg}$ is associated with failure to control bleeding as well as higher rate of rebleeding and higher 1-year mortality [47]. Transjugular intrahepatic portosystemic shunt (TIPSS) is the percutaneous placement of a stent between the hepatic vein and intrahepatic segment of the portal vein in order to reduce portal pressure. A reduction in HVPG to $<12$ $\mathrm{mm} \mathrm{Hg}$ or by $20 \%$ from the baseline value reduces the risk of variceal haemorrhage and improves survival. Complications of this treatment include hepatic encephalopathy due to systemic exposure to toxin-containing blood and heart failure due to the sudden increase in cardiac preload [48].

\section{Secondary prevention of variceal haemorrhage}

Without additional therapy, patients affected by a variceal bleeding episode have a $60 \%$ chance of rebleeding within 1-2 years with a $33 \%$ mortality [7]. $\beta$-blockers such as propranolol and carvedilol has been shown to significantly reduce rebleeding and mortality $[49,50]$. The combination of this type of drugs and nitrates is superior to $\beta$-blocker monotherapy but is associated with more side effects and is poorly tolerated [51]. In addition, periodic gastroscopy with or without band ligation if it is necessary have been observed to significantly reduce the median rebleeding rate to around 32\% [52]. Patients who rebleed despite optimal pharmacological and endoscopic therapy or those who are intolerant to that approach, can be considered for TIPSS. 
Tables

Table 1: Main cause of acute upper gastrointestinal bleeding. UGIB: Upper gastrointestinal bleeding. NSAIDs: non-steroidal anti-inflammatory drugs

\begin{tabular}{|l|l|}
\hline \multicolumn{1}{|c|}{ NON-VARICEAL UGIB (80-90\%): } & \multicolumn{1}{|c|}{ VARICEAL UGIB (10-20\%) } \\
\hline $\begin{array}{l}\text { Gastroduodenal peptic ulcer (40-50\%): It is the most } \\
\text { frequent cause. Mainly by Helicobacter pylori and intake of } \\
\text { (NSAIDs). }\end{array}$ & $\begin{array}{l}\text { Hemorrhage due to esophageal varicose veins (75\%) or gas- } \\
\text { tric varicose veins (10\%): They are frequently observed in cir- } \\
\text { rhotic patients with a mortality rate of 30\%. High risk of sepsis } \\
\text { and spontaneous bacterial peritonitis. }\end{array}$ \\
\hline $\begin{array}{l}\text { Acute lesions of the gastroduodenal mucosa (erosive and } \\
\text { hemorrhagic gastritis) (10-15\%): Caused by unsuccessful } \\
\text { endoscopic therapy, prolonged use of NSAIDs, stress and } \\
\text { alcohol intake. }\end{array}$ & $\begin{array}{l}\text { Hemorrhage due to gastropathy of portal hypertension: It is } \\
\text { very rare. It is produced by dilatation of venules and capillaries } \\
\text { of mucosa and gastric submucosa in the absence of erosive or } \\
\text { inflammatory phenomena, which is characteristically associ- } \\
\text { ated with portal hypertension. }\end{array}$ \\
\hline $\begin{array}{l}\text { Mallory-Weiss syndrome (15-20\%): In patients with a history } \\
\text { of vomiting with intense arches that lead to hemorrhages and } \\
\text { even perforation. Lacerations occur in the gastroesophageal } \\
\text { junction. It yields spontaneously in most cases. }\end{array}$ & $\begin{array}{l}\text { Esophagitis (5-10\%): Uncommon cause. It usually presents as } \\
\text { occult hemorhage. Endoscopic treatment is useful in case of } \\
\text { ulcerations or bleeding visible vessels. }\end{array}$ \\
\hline
\end{tabular}

Table 2: Blatchford score. Scores of 0-3 points are patients categorized as low risk. These patients may be discharged with an upper digestive endoscopy in 24-48 hours. Score values higher than 3 points require an urgent upper gastrointestinal endoscopy.

\begin{tabular}{|c|c|c|}
\hline \multicolumn{3}{|c|}{ BLATCHFORD SCORE } \\
\hline Admission & risk marker & Score component value \\
\hline \multicolumn{3}{|c|}{ Blood urea (mmol/L) } \\
\hline$\bullet$ & $\geq 6.5<8.0$ & 2 \\
\hline$\bullet$ & $\geq 8.0<10.0$ & 3 \\
\hline • & $\geq 10.0<25.0$ & 4 \\
\hline - & $\geq 25$ & 6 \\
\hline \multicolumn{3}{|c|}{ Haemoglobin (g/L) for men } \\
\hline$\bullet$ & $\geq 12.0<13.0$ & 1 \\
\hline • & $\geq 10.0<12.0$ & 3 \\
\hline - & $\geq 10.0$ & 6 \\
\hline \multicolumn{3}{|c|}{ Haemoglobin (g/L) for women } \\
\hline 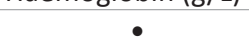 & $\geq 10.0<12.0$ & 1 \\
\hline$\bullet$ & $\geq 10.0$ & 6 \\
\hline \multicolumn{3}{|c|}{ Systolic blood pressure (mmHg) } \\
\hline$\bullet$ & 100-109 & 1 \\
\hline$\bullet$ & $90-99$ & 2 \\
\hline$\bullet$ & $<90$ & 3 \\
\hline \multicolumn{3}{|l|}{ Other markers } \\
\hline$\bullet$ & Pulse $\geq 100$ (per & 1 \\
\hline - & Presentation with & 1 \\
\hline $\begin{array}{l}\bullet \\
\text { syncope }\end{array}$ & Presentation with & 2 \\
\hline - & Hepatic disease & 2 \\
\hline$\bullet$ & Cardiac failure & 2 \\
\hline
\end{tabular}


Table 3: Rockall score. Scores < 2 points are patients categorized as low risk. Scores between 3-4 points implies intermediate risk. Finally, scores higher than 5 are patients categorized as high risk. However, patients categorized as low risk but present blood in the stomach, hematocrit less than $30 \%$ or hypotension increase its score to intermediate risk.

\begin{tabular}{|c|c|c|c|c|}
\hline \multicolumn{5}{|c|}{ ROCKALL SCORE } \\
\hline \multirow{2}{*}{ Variable } & \multicolumn{4}{|c|}{ Score } \\
\hline & 0 & 1 & 2 & 3 \\
\hline Age & No shock & $\begin{array}{l}\text { Pulse }>100, \text { Systolic blood } \\
\text { pressure }>100 \mathrm{mmHg}\end{array}$ & $\begin{array}{c}\text { Systolic blood pressure }<100 \\
\mathrm{mmHg}\end{array}$ & \\
\hline Shock & No shock & $\begin{array}{c}\text { Pulse }>100, \text { Systolic blood } \\
\text { pressure }>100 \mathrm{mmHg}\end{array}$ & $\begin{array}{c}\text { Systolic blood pressure }<100 \\
\mathrm{mmHg}\end{array}$ & \\
\hline Comorbidity & Nil major & & $\begin{array}{l}\text { Heart failure, ischaemic heart } \\
\text { disease, major comorbidity }\end{array}$ & $\begin{array}{c}\text { Renal failure, liver } \\
\text { failure, metastatic } \\
\text { cancer }\end{array}$ \\
\hline Endoscopy & $\begin{array}{l}\text { None disturbs or } \\
\text { Mallory-Weiss }\end{array}$ & All other diagnoses & $\begin{array}{c}\text { Gastrointestinal malignancy, } \\
\text { blood, adherent clot, spurting } \\
\text { vessel }\end{array}$ & \\
\hline
\end{tabular}

\section{Conclusions}

UGIB represents approximately 48 to 160 cases per 100,000 adults, with a mortality rate of $10 \%$ to $14 \%$. A correct anamnesis to determine the severity as well as the prognosis of the hemorrhage is necessary, but this not may delay the initiation of hemodynamic resuscitation. Blatchford score as well as Rockall score are useful tools to determine the patient risk. Diagnosis is determined by endoscopic techniques which should be realized as soon as possible. In addition, this technique provides the possibility to perform a definitive treatment in non variceal hemorrhage as well as variceal hemorrhage. In addition, after the endoscopy treatment, both etiologies have been observed to increase its outcomes applying PPI therapy. If endoscopy treatment fails in variceal hemorrhage, balloon tamponade or TIPSS are indicated.

\section{References}

1. Laine L. CLINICAL PRACTICE. Upper Gastrointestinal Bleeding Due to a Peptic Ulcer. N Engl J Med. 2016; 374 (24)

2. Lassen A, Hallas J, Schaffalitzky de Muckadell OB. Complicated and uncomplicated peptic ulcers in a Danish county 1993-2002: a population-based cohort study. Am J Gastroenterol 2006; 101: 945-53. doi:

3. Targownik LE, Nabalamba A. Trends in management and outcomes of acute nonvariceal upper gastrointestinal bleeding: 1993-2003. Clin Gastroenterol Hepatol 2006; 4: 1459-66.

4. Quan S, Frolkis A, Milne K, Molodecky N, Yang H, Dixon E, Ball CG, Myers RP, Ghosh S, Hilsden R, van Zanten SV, Kaplan GG. Upper-gastrointestinal bleeding secondary to peptic ulcer disease: incidence and outcomes. World J Gastroenterol 2014; 20: 17568-77.

5. Lu Y, Barkun AN, Martel M. Adherence to guidelines: a national audit of the management of acute upper gastrointestinal bleeding. The REASON registry. Can J Gastroenterol Hepatol 2014; 28: 495-501.

6. Rotondano G. Epidemiology and diagnosis of acute nonvariceal upper gastrointestinal bleeding. Gastroenterol Clin North Am 2014; 43(4): 643-63.

7. Jafar W, Jafar AJN, Sharma A. Upper gastrointestinal haemor- rhage: an update. Frontline Gastroenterol. 2016; 7(1): 32-40.

8. Biecker E. Diagnosis and therapy of non-variceal upper gastrointestinal bleeding. World J Gastrointest Pharmacol Ther. 2015; 6(4): 172-82.

9. Ahsberg K, Höglund P, Kim WH, von Holstein CS. Impact of aspirin, NSAIDs, warfarin, corticosteroids and SSRIs on the site and outcome of non-variceal upper and lower gastrointestinal bleeding. Scand J Gastroenterol. 2010; 45(12): 1404-15.

10. Baradarian R, Ramdhaney S, Chapalamadugu R, Skoczylas L, Wang K, Rivilis S, Remus K, Mayer I, Iswara K, Tenner S. Early intensive resuscitation of patients with upper gastrointestinal bleeding decreasesmortality. Am J Gastroenterol. 2004; 99(4): 619-22.

11. Barkun AN, Bardou M, Kuipers EJ, Sung J, Hunt RH, Martel M, Sinclair P; International ConsensusUpper Gastrointestinal Bleeding Conference Group. International consensus recommendations on the management of patients with nonvaricealupper gastrointestinal bleeding. Ann Intern Med. 2010; 152(2): 10113.

12. Villanueva C, Colomo A, Bosch A. Transfusion for acute upper gastrointestinal bleeding. N Engl J Med 2013; 368: 1362-3.

13. Wang J, Bao YX, Bai M, Zhang YG, Xu WD, Qi XS. Restrictive vs liberal transfusion for upper gastrointestinal bleeding: a metaanalysis of randomized controlled trials. World J Gastroenterol 2013; 19: 6919-27.

14. Villanueva C, Colomo A, Bosch A, Concepción M, HernandezGea V, Aracil C, Graupera I, Poca M, Alvarez-Urturi C, Gordillo J, Guarner-Argente C, Santaló M, Muñiz E, Guarner C. Transfusion strategies for acute upper gastrointestinal bleeding. $\mathrm{N}$ Engl J Med. 2013; 368(1): 11-21.

15. NICE. Acute upper gastrointestinal bleeding: management. National Institute of Clinical Excellence clinical guideline 1412012.

16. Blatchford O, Murray WR, Blatchford M. A risk score to predict need for treatment for upper-gastrointestinal haemorrhage. Lancet 2000; 356: 1318-21.

17. Rockall TA, Logan RF, Devlin HB, Northfield TC. Risk assessment after acute upper gastrointestinal haemorrhage. Gut. 1996; 38(3): 316-21. 
18. Shah A, Chisolm-Straker M, Alexander A, Rattu M, Dikdan S, Manini AF. Prognostic use of lactate to predict inpatient mortality in acute gastrointestinal hemorrhage. Am J Emerg Med. 2014; 32(7): $752-5$

19. El-Kersh K, Chaddha U, Sinha RS,Saad M,Guardiola J , Cavallazzi R. Predictive Role of Admission Lactate Level in Critically III Patients with Acute UpperGastrointestinal Bleeding. J Emerg Med. 2015; 49(3): 318-25.

20. Ko BS, Kim WY, Ryoo SM, Ahn S, Sohn CH, Seo DW, Lee YS, Lim KS, Jung HY. Predicting the Occurrence of Hypotension in Stable Patients With Nonvariceal UpperGastrointestinal Bleeding: Point-of-Care Lactate Testing. Crit Care Med. 2015 Nov; 43(11): 2409-15.

21. Srygley FD, Gerardo CJ, Tran T, Fisher DA. Does this patient have a severe upper gastrointestinal bleed? JAMA. 2012; 307(10): 1072-9.

22. Leontiadis GI, Sreedharan A, Dorward S, Barton P, Delaney B, Howden CW, Orhewere M, Gisbert J, Sharma VK, Rostom A, Moayyedi P, Forman D. Systematic reviews of the clinical effectiveness and cost-effectiveness of proton pump inhibitors in acute upper gastrointestinal bleeding. Health Technol Assess. 2007; 11(51): iii-iv, 1-164.

23. Roberts I, Shakur H, Coats T, Hunt B, Balogun E, Barnetson L, Cook L, Kawahara T, Perel P, Prieto-Merino D, Ramos M, Cairns J, Guerriero C. The CRASH-2 trial: a randomized controlled trial and economic evaluation of the effects of tranexamic acid on death, vascular occlusive events and transfusion requirement in bleedingtrauma patients. Health Technol Assess. 2013; 17(10): 1-79.

24. Roberts I, Coats T, Edwards P, Gilmore I, Jairath V, Ker K, Manno D, Shakur H, Stanworth S, Veitch A. HALT-IT-tranexamic acid for the treatment of gastrointestinal bleeding: study protocol for a randomised controlled trial. Trials. 2014; 15: 450

25. Spiegel BM, Vakil NB, Ofman JJ. Endoscopy for acute nonvariceal upper gastrointestinal tract hemorrhage: is sooner better? A systematic review. Arch Intern Med 2001;161:1393-404.

26. Calvet X, Vergara M, Brullet E, Gisbert JP, Campo R. Addition of a second endoscopic treatment following epinephrine injection improves outcome in high-risk bleeding ulcers. Gastroenterology. 2004; 126(2): 441-50.

27. Marmo R, Rotondano G, Bianco MA, Piscopo R, Prisco A, Cipolletta L. Outcome of endoscopic treatment for peptic ulcer bleeding: Is a second look necessary? A meta-analysis. Gastrointest Endosc. 2003; 57(1): 62-7.

28. Giday SA, Kim Y, Krishnamurty DM, Ducharme R, Liang DB, Shin EJ, Dray X, Hutcheon D, Moskowitz K, Donatelli G, Rueben D, Canto MI, Okolo PI, Kalloo AN. Long-term randomized controlled trial of a novel nanopowder hemostatic agent (TC-325) for control of severe arterial upper gastrointestinal bleeding in a porcine model. Endoscopy. 2011; 43(4): 296-9.

29. Babiuc RD, Purcarea M, Sadagurschi R, Negreanu L. Use of Hemospray in the treatment of patients with acute UGIB - short review. J Med Life. 2013; 6(2): 117-9.

30. Smith LA, Morris AJ, Stanley AJ. The use of hemospray in portal hypertensive bleeding; a case series. J Hepatol 2014; 60: 45760.

31. Leontiadis GI, Howden CW. Pharmacologic treatment of peptic ulcer bleeding. Curr Treat Options Gastroenterol 2007; 10: 13442.

32. Lin HJ, Lo WC, Lee FY, Perng CL, Tseng GY. A prospective randomized comparative trial showing that omeprazole prevents rebleeding in patients with bleeding peptic ulcer after successful endoscopic therapy. Arch Intern Med 1998; 158: 54-8.

33. Lau JY, Sung JJ, Lee KK, Yung MY, Wong SK, Wu JC, Chan FK, Ng EK, You JH, Lee CW, Chan AC, Chung SC. Effect of intravenous omeprazole on recurrent bleeding after endoscopic treatment of bleeding peptic ulcers. N Engl J Med 2000; 343: 310-16.

34. Zargar SA, Javid G, Khan BA, Yattoo GN, Shah AH, Gulzar GM, Sodhi JS, Mujeeb SA, Khan MA, Shah NA, Shafi HM. Pantoprazole infusion as adjuvant therapy to endoscopic treatment in patients with peptic ulcer bleeding: prospective randomized controlled trial. J Gastroenterol Hepatol 2006; 21: 716-21.

35. Gisbert JP, Khorrami S, Carballo F, Calvet X, Gene E, DominguezMuñoz E. Meta-analysis: Helicobacter pylori eradication therapy vs. antisecretory non-eradicationtherapy for the prevention of recurrent bleeding from peptic ulcer. Aliment Pharmacol Ther. 2004; 19(6): 617-29.

36. Liu CC, Lee CL, Chan CC, Tu TC, Liao CC, Wu CH, Chen TK. Maintenance treatment is not necessary after Helicobacter pylori eradication and healing of bleeding peptic ulcer: a 5-year prospective, randomized, controlled study. Arch Intern Med. 2003; 163(17): 2020-4.

37. Bhatt DL, Cryer BL, Contant CF, Cohen M, Lanas A, Schnitzer TJ, Shook TL, Lapuerta P, Goldsmith MA, Laine L, Scirica BM, Murphy SA, Cannon CP; COGENT Investigators. Clopidogrel with or without omeprazole in coronary artery disease. N Engl J Med. 2010; 363(20): 1909-17.

38. Ali SM, Wu S, Xu H, Liu H, Hao J, Qin C. A Prospective Study of Endoscopic Injection Sclerotherapy and Endoscopic Variceal Ligation in the Treatment of Esophageal Varices. J Laparoendosc Adv Surg Tech A. 2017; 27(4): 333-341.

39. Ríos Castellanos E, Seron P, Gisbert JP, Bonfill Cosp X. Endoscopic injection of cyanoacrylate glue versus other endoscopic procedures for acute bleeding gastric varices in people with portal hypertension. Cochrane Database Syst Rev. 2015; (5): CD010180.

40. Ioannou GN, Doust J, Rockey DC. Systematic review: terlipressin in acute oesophageal variceal haemorrhage. Aliment Pharmacol Ther 2003; 17: 53-64.

41. Hung TH, Tsai CC, Tseng CW, Tseng KC, Hsieh YH, Tsai CC. No difference in mortality between terlipressin and somatostatin treatments in cirrhotic patients with esophageal variceal bleeding and renal functional impairment. Eur J Gastroenterol Hepatol. 2016; 28(11): 1275-9.

42. Hung TH, Tsai CC, TsenK GC, Hsieh YH, Tseng CW. No mortality difference following treatment with terlipressin or somatostatin in cirrhotic patients with gastric variceal hemorrhage. Saudi J Gastroenterol. 2016; 22(3): 220-5.

43. Goulis J, Patch D, Burroughs AK. Bacterial infection in the pathogenesis of variceal bleeding. Lancet 1999; 353: 139-42.

44. Hidaka H, Nakazawa T, Wang G, Kokubu S, Minamino T, Takada J, Tanaka Y, Okuwaki Y, Watanabe M, Tanabe S, Shibuya A, Koizumi W. Long-term administration of PPI reduces treatment failures after esophageal variceal bandligation: a randomized, controlled trial. J Gastroenterol. 2012; 47(2): 118-26.

45. Shaheen NJ, Stuart E, Schmitz SM, Mitchell KL, Fried MW, Zacks S, Russo MW, Galanko J, Shrestha R. Pantoprazole reduces the size of postbanding ulcers after variceal band ligation: a randomized, controlled trial. Hepatology. 2005; 41(3): 588-94.

46. Chang CJ, Hou MC, Liao WC, Chen PH, Lin HC, Lee FY, Lee SD. Management of acute gastric varices bleeding. J Chin Med Assoc. 2013; 76(10): 539-46. 
47. Moitinho E, Escorsell A, Bandi JC, Salmerón JM, García-Pagán JC, Rodés J, Bosch J. Prognostic value of early measurements of portal pressure in acute variceal bleeding. Gastroenterology. 1999; 117(3): 626-31.

48. D’Amico G, Garcia-Pagan JC, Luca A, Bosch J. Hepatic vein pressure gradient reduction and prevention of variceal bleeding in cirrhosis: a systematic review. Gastroenterology. 2006;131(5): 1611-24.

49. Cheng JW, Zhu L, Gu MJ, Song ZM. Meta analysis of propranolol effects on gastrointestinal hemorrhage in cirrhotic patients. World J Gastroenterol. 2003; 9(8): 1836-9.

50. Reiberger T, Ulbrich G, Ferlitsch A, Payer BA, Schwabl P, Pinter M, Heinisch BB, Trauner M, Kramer L, Peck-Radosavljevic M; Vienna Hepatic Hemodynamic Lab. Carvedilol for primary prophylaxis of variceal bleeding in cirrhotic patients with haemodynamicnon-response to propranolol. Gut. 2013; 62(11): 1634-41.
51. Gournay J, Masliah C, Martin T, Perrin D, Galmiche JP. Isosorbide mononitrate and propranolol compared with propranolol alone for the preventionof variceal rebleeding. Hepatology. 2000; 31(6): 1239-45.

52. Bosch J, Garcia-Pagan JC. Prevention of variceal rebleeding. Lancet 2003; 361: 952-4. 